研 觉 報 文

\title{
複写古紙の脱墨過程における紙の構成成分およびトナーの量的変化
}

\author{
東京大学大学院農兴生命科学研究科 生物材料科学専攻製紙科学研究室 \\ 申 准䜴, 磯具 明，尾鍋史彦
}

\section{Quantitative Changes in Paper Components and Toner during Deinking Processes of Wastes of Copying Paper}

\author{
Jun-Seop Shin, Akira Isogai and Fumihiko Onabe \\ Graduate School of Agricultural and Life Sciences, The \\ University of Tokyo
}

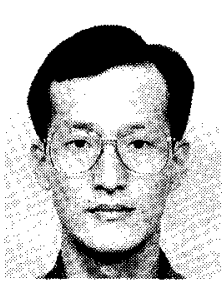

中 准維

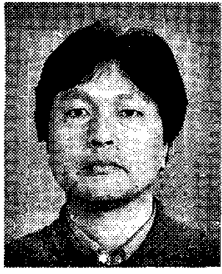

磯貝 明

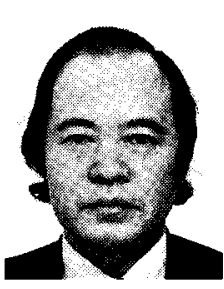

尾鍋史彦

Quantitative changes in paper components and toner during deinking processes of wastes of copying paper were studied using analytical techniques, such as energy dispersive X-ray analysis (EDXA), glucose sensor, pyrolysis-gas chromatography ( $\mathrm{Py}-\mathrm{GC}$ ), and image analysis. First, the method for determining residual toner content in recycled handsheets were established by means of $\mathrm{Py}-\mathrm{GC}$. Brightness and $\mathrm{k} / \mathrm{s}$ values also had good correlation with the residual toner content. Percentages of toner area obtained by image analysis of the recycled handsheets were, however, found to be unsuitable for evaluating the residual toner content. Since disintegration at temperatures lower than the grass transition temperature $\left(65^{\circ} \mathrm{C}\right)$ of toner binder was better for removing the toner, disintegration under alkaline conditions was carried out at $50^{\circ} \mathrm{C}$ in this study. The original copied paper contained calcium carbonate filler, ASA (alkenyl succinic anhydride)size, aluminum compounds originating from alum, and starches originating from wet-end additives and a surface size. Quantitative changes in these paper components and toner were evaluated for recycled handsheets in terms of the following deinking stages ; 1) disintegration under alkaline conditions, 2) disintegration under alkaline conditions with a deinking agent, 3) bleaching treatment with hydrogen peroxide, and 4) flotation treatment.

Most of filler, size, aluminum and starch present in the original copied paper were removed by the disintegration process under alkaline conditions followed by the handsheetmaking. The residual toner content gradually decreased as the disintegration, deinking agent treatment and bleaching treatment proceeded, although only lower than $17 \%$ of the toner was removed from the wastes of copying paper by these treatments. More than $80 \%$ of the toner was removed by the flotation treatment. However, since yields of recycled pulp after the flotation treatment was $67-74 \%$, the removal of the toner in the flotation process was accompanied with the partial loss of pulp fibers; removal of toner components from fibers did not proceed efficiently during the processes used in this study. Thus, more 
efficient removal of toner components was necessary for utilization of wastes of copying paper.

Keywords: Copied paper, Toner, Py-GC, Flotation, Glass transition temperature, Filler, Starch, Brightness.

\section{1. 緒言}

最近，古紙の利用率をさらに向上させようとする動 きが一段と活発になってきた。中でも，古紙の利用率 を 2000 年までに $56 \%$ にしょうとする「リサイクル 56 計画」がその一例として挙げられる。古紙利用率をこ のように向上させるには様々な手段が考えられるが, オフィスの情報関連機器から出てくる，いわゆるオフ イス古紙の利用拡大がその一つの鍵である。

1994 年度の日本の古紙利用率は $53.3 \%$ と製紙原料 の半分を越えたが1), その内容をみると, 新聞・雑誌 古紙，段ボール古紙の利用が大部分である。一方，才 フィス古紙の場合は回収率も高くないが, 更に, 回収 された古紙はほとんどが板紙の原料として使用されて おり，印刷・筆記用紙に再生されるのは 1 2\%にと どまっている。

オフィス古紙には各種の古紙が混ざっており, MOW (Mixed office waste) と表現されるが, 電子 複写機の使用により発生する複写古紙 (Wastes of copying paper) やレーザープリンターの印字により 発生するレーザープリンター古紙 (Laser-printed wastepaper）が主なものであり，雨者の印字方式は ほぼ同じである。

オフィス古紙の中でも, 複写古紙には上質パルプが 多く含有されており, 再生資源としての利用価值が高 い。しかし, 従来の脱墨方式ではトナーの分離がかな り困難であり ${ }^{2)}$, より効果の高い脱墨剤や脱墨システ ムの開発を目指した研究が活発になっている ${ }^{3-7)}$ 。

以上のような古紙の利用技術の開発とともに，古紙 の評価・分析技術, 中でも, 再生紙に残留するインキ の分析方法が重要となってきたが, 従来, 残留インキ による反射率の変化で評価する白色度が一般的方法で あった。最近ではこれと共にスキャナーから取り込ん だ画像をコンピュータ解析し, 紙の表面上の一定大き さ以上の残留インキの個所及び面積率を計算する方法 も行われている ${ }^{8-12)}$ 。また Jordan と Popson は新聞 古紙に対し, 紙とインキの光吸収係数を利用した式か ら残留インキ量を求めている ${ }^{13)}$ 。

一般にオフィス用紙には, サイズ剤, 塡料, 歩留り 向上剤, 紙力増強剤, 表面サイズ剤等の複数の成分が
含まれており，これらのオフィス用紙成分は古紙の脱 墨過程で部分的に失われるものと考えられる。オフィ ス古紙中のトナーやトナーバインダーのみならず，才 フィス用紙に本来含まれていた構成成分の脱墨過程に おける挙動を明らかにすることは, 得られるオフィス 古紙の特性や利用を考える上で重要であるばかりでな く, 古紙の脱墨を行う際の廃萧物や排水の管理の上で も重要である。

そこで本研究では, 占紙の脱量過程によるトナ一成 分の変化に伴い，オフィス用紙の構成成分，すなわち， 填料, デンプン, 歩留り向上骺の残留量がどのように 変化するかを調べるため, オフィス古紙の一種である 複写古紙の脱墨過程を取り上げて検討した。また，特 に残留トナー量の測定法としては熱分解 GC (PyGC) の応用可能性を検討した。

\section{2. 実験}

\section{1 古紙試料の調製}

古紙試料としては, 市販の坪量 $68.0 \mathrm{~g} / \mathrm{m}^{2}$ の複写 用紙を電子写真方式のコピー機を啝いて， $5 \times 5 \mathrm{~cm} の$ 正方形のべな望り部分を基本単位として印刷面積（ト ナー被覆面積）０～100\%に印字して得な。離解を容易 にするために予め試料を約 $2 \mathrm{~cm} \times 2 \mathrm{~cm}$ の細片に切断 した。

\section{2 古紙の処理}

2.1 で調製した古紙の離解, 漂白及び熟成, フロー テーションなどの脱墨処理は次のような流れで行った (図 1)。

\section{（1）離解及び漂白}

離解はパルプ濃度 $5 \%$, 温度 $50^{\circ} \mathrm{C}$ の条件で TAPPI 標準法の T 205 sp-95 で示されている離解機を用いて 15 分間行った。離解する際に水酸化ナトリウムのみ を添加して得たパルプを T 1 , 脱墨剤と水酸化ナトリ ウムを一括添加して処理したパルプを T2 とする (表 1)。市販の脱墨剤（固形分 $=90 \%$, 花王(検) を $10 \%$ に希䣋し, 水酸化ナトリウム (特級試薬, 和光純 薬(株)を $30 \%$ の溶液にしてそれぞれ添加した。離解後,

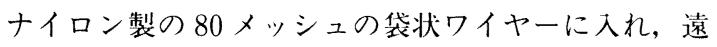
心脱水してパルプ濃度 $25 \%$ まで濃縮した。

脱水濃縮したパルプ T 2 に, 水酸化ナトリウム 
Table 1 Conditions of deinking treatments

\begin{tabular}{cl}
\hline Treatment & \multicolumn{1}{c}{ Sequence } \\
\hline T 1 & Disintegration $(\mathrm{NaOH}, 1.5 \%)$ \\
T 2 & Disintegration $(\mathrm{NaOH}, 1.5 \%+$ deinking agent, $0.35 \%)$ \\
T 3 & Disintegration $(\mathrm{NaOH}, 1.5 \%+$ deinking agent, $0.35 \%)$ and flotation \\
T 4 & Disintegration $(\mathrm{NaOH}, 1.5 \%+$ deinking agent, $0.35 \%)$ and bleaching $\left(\mathrm{Na}_{2} \mathrm{SiO}_{3}\right.$, \\
& $\left.3.0 \%+\mathrm{NaOH}, 1.0 \%+\mathrm{H}_{2} \mathrm{O}_{2}, 1.0 \%\right)$ \\
T 5 & Disintegration $(\mathrm{NaOH}, 1.5 \%+$ deinking agent, $0.35 \%)$, bleaching $\left(\mathrm{Na}_{2} \mathrm{SiO}_{3}\right.$, \\
& $\left.3.0 \%+\mathrm{NaOH}, 1.0 \%+\mathrm{H}_{2} \mathrm{O}_{2}, 1.0 \%\right)$ and flotation \\
\hline
\end{tabular}

Percentages represent weight percent on dry weight of papersheets.

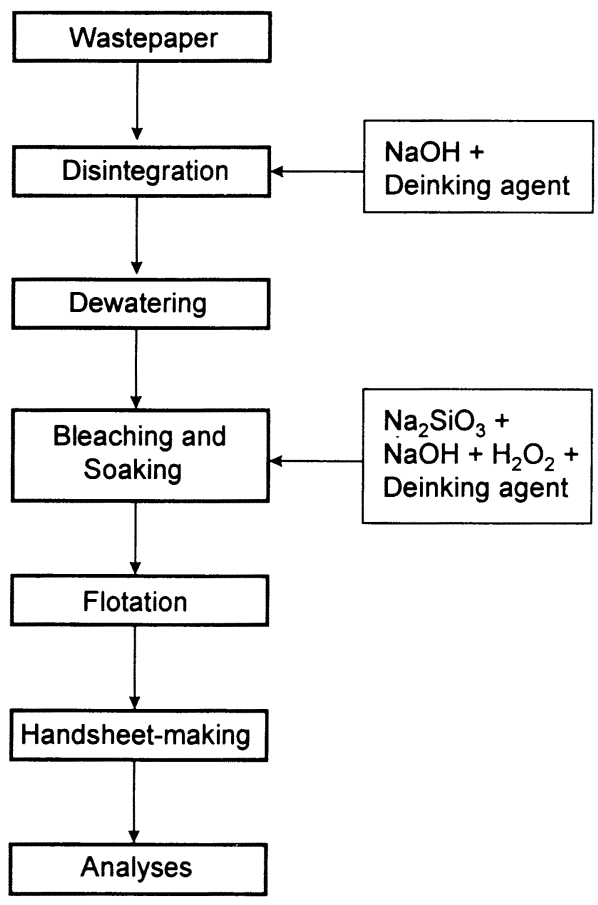

Fig.1 Flowchart of deinking processes.

$1.5 \%$ ，ケイ酸ナトリウム $3.0 \%$, 過酸化水素 $1.0 \%$, 脱墨剤 $0.15 \%$ （いずれも対絶乾パルプ重量比）を添 加し, $60^{\circ} \mathrm{C} て ゙ 2$ 時閒漂白及び熟成を行った。この漂白 段階まで処理したパルプを T 4 とする。

(2) フローテーション

脱墨戍と水酸化ナトリウムで離解したパルプ ( T 2）または，更に漂白を行ったパルプ（T 4)をそれ ぞれ離解機で約 1 分間再離解を行った後, 水を加えて パルプ濃度を $1 \%$ とし，水温を $50^{\circ} \mathrm{C}$ に保ち，フローテ 一ター（FW 型浮遊選別試験機，共伸産業㑣）を用 い15 分間フローテーション処理を行った。

（3）脱水及びサンプルシートの調製
T 2, T 4 のパルプにフローテーション処理を行つ たパルプをそれぞれT $3 ， \mathrm{~T} 5$ とし， 80 メッシュのワ イヤーを用いて固形分 $10 \%$ にまで濃縮した後, 希䣋 して TAPPI 標準法に従い坪量 $80 \mathrm{~g} / \mathrm{m}^{2}$ の手抄きシー 卜を調製した。また, 各処理パルプの一部を採取し, 纎維長測定機（Kajaani-FS 200）を用いて繊維長分 布を測定した。

\section{3 オフィス古紙の構成成分の測定}

脱墨各処理段階における構成成分の変化は以下の方 法で測定した。

(1) 塡料とアルミニウム化合物

本研究で用いた複写用紙に含まれる填料及びアルミ ニウム化合物の量的変化の分析については，エネルギ 一分散型 X 線分析装置 (EDX : EMAX-5770 X, 堀 場(株)）を付属した走査型電子顕微鏡（SEM：S-4000, 日立秼）を用いた。各処理を行った手抄きシートのプ レート面を 100 秒間プラチナコートし，以下の条件で 元素分析を行った：SEMの電子線発生条件 $20 \mathrm{kV}$, 倍率 40 倍, EDX の測定時間 500 秒, 定量モード P 5。 プラチナコートを各試料同時に行うことにより，各試 料とも同一量のプラチナがコートされたと見なし，プ ラチナのピークに対する堙料成分やアルミニウムのピ 一クの相対值を求めた。

(2) デンプン

シート中のデンプンの定量にはグルコースセンサー （BF-3 T，新王子製紙(株)）を用いた ${ }^{14)}$ 。報告に従い， 二種類のアミラーゼを用いてシート中のデンプンをグ ルコースに加水分解した後，グルコースセンサーで定 量した。

(3) コピートナー

再生紙中のトナーの残留量測定には熱分解 GC (Py$\mathrm{GC}$ ：島津(株の GC-14 B に Yanaco 社の GP-1018 を 付属させた）を用いて行った。測定条件は, 熱分解温 度 $450^{\circ} \mathrm{C}$, 注入部温度 $250^{\circ} \mathrm{C}, \mathrm{FID}$ 検出器温度 $280^{\circ} \mathrm{C}$, 
カラム温度は初期温度 $150^{\circ} \mathrm{C} と し て 5^{\circ} \mathrm{C} / \mathrm{min}$ で $300^{\circ} \mathrm{C}$ まで昇温した。それぞれの試料に対して最低 3 问の測定を行い平均を求妉。同様に, シート中のサ イズ剤成分の定量も行った ${ }^{15)}$ 。また，スキャナーを用 いて再生手抄きシートの $5 \mathrm{~cm} \times 5 \mathrm{~cm}$ の領域から 600 dpi で画像を撮り込み, $1,200 \mathrm{dpi}$ の出力でトナー部 分の面積を画像解析によって求める方法も用いた。そ の際の画素数は 561 万で, 255 のグレーレベルからし きい值によって二值化してトナ一部分の面積を求めた。 しきい值としては200と215を選択した。トナーの DSC 分析には, Perkin Elmer 社製 DSC 7 を用いて $5^{\circ} \mathrm{C} /$ 分の昇温速度で空気の存在下で測定した。

\section{3. 結果及び考察}

\section{1 残留トナー量の定量}

(1) 熱分解 GCによる残留トナー量の測定 複写機用トナー粉末を熱分解 GC で分析したところ,

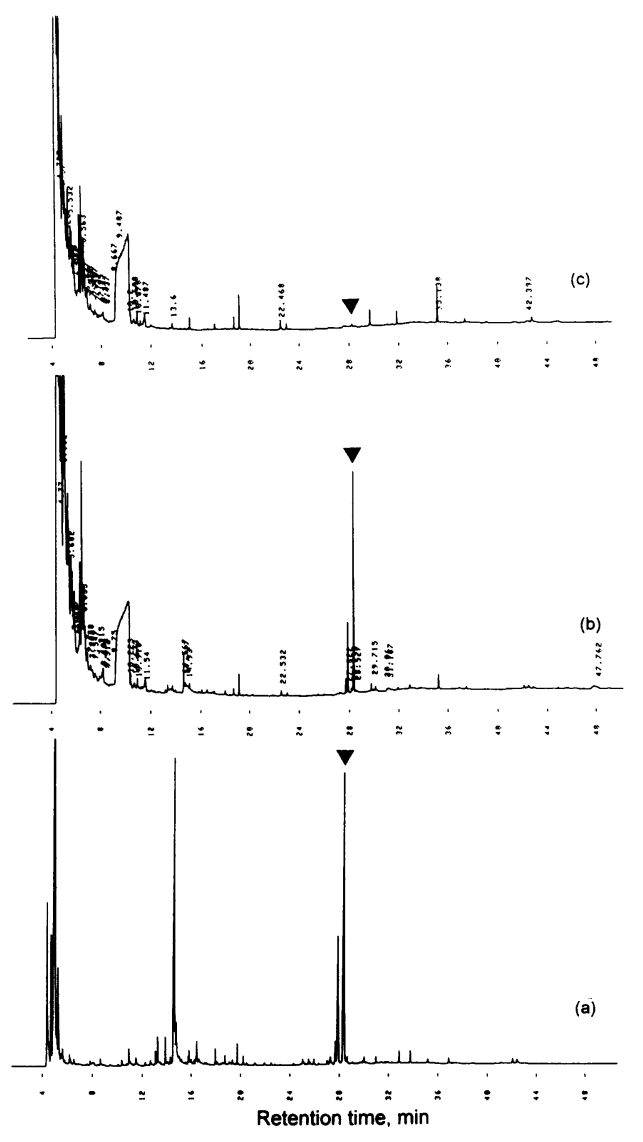

Fig.2 Pyrolysis-gas chromatograms of PPC toner (a), wastepaper (b), and recycled handsheet $(\mathrm{c})$ treated by $\mathrm{T} 5$ in Table 1.
図 2 に示すようにパルプの熟分解物のピークとは分離 できる位置に 2 本（保持時間 $=27.6$ と 28.5 分）の典 型的なピークを与えた。これらのピークを熱分解 $\mathrm{GC}$ MSによって分析したところ，トナーのバインダー成 分の一種と考之られ, 分子量 300 400 程度のベンゼ ン環を含むアルキル鎖であった。GC-MSのフラグメ ントとしては以下の分子量のピークが現れた。保持時 間 27.6 分のピーク : $\mathrm{m} / \mathrm{e}=57,77,91,105,117$, 131，145，163，176，207，218，232，263。保持時間 28.5 分のピーク $: \mathrm{m} / \mathrm{e}=91,117,194,207$ 。レーザ ープリンター用トナーにもほぼ间㥞の物質が令まれて おり，これらのピーク面積からオフィス、紙梳の残留 トナー量を測定できる叮能性がある。

そこで，コピー面積が 0 〜 50\%の 6 種類の十古紙を調 製し，離解だけを行って乎抄きシートを調製し，熱分 解 GCによって，コピー面積と熱分解 GCによるピー ク面積との関係を調べた。その結果, 図 3 に亦すよう にコピー面積と熱分解 GCによるトナ一成分由米のヒ 一ク面積の間には良好な比例関係が得られた。网 3 に おける相関係数は 0.9932 であった。この結果から, 熱分解 GCのピーク面積から，汁紙中の残留卜ナ一量 を定量できることが示された。コピー泊積 $50 \%$ の際

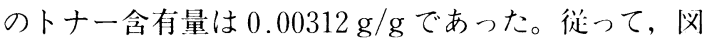
3 の直線関係から，トナー成分のピークの解積比とシ 一トに残留しているトナー重量の関係は次のような式 で示される。

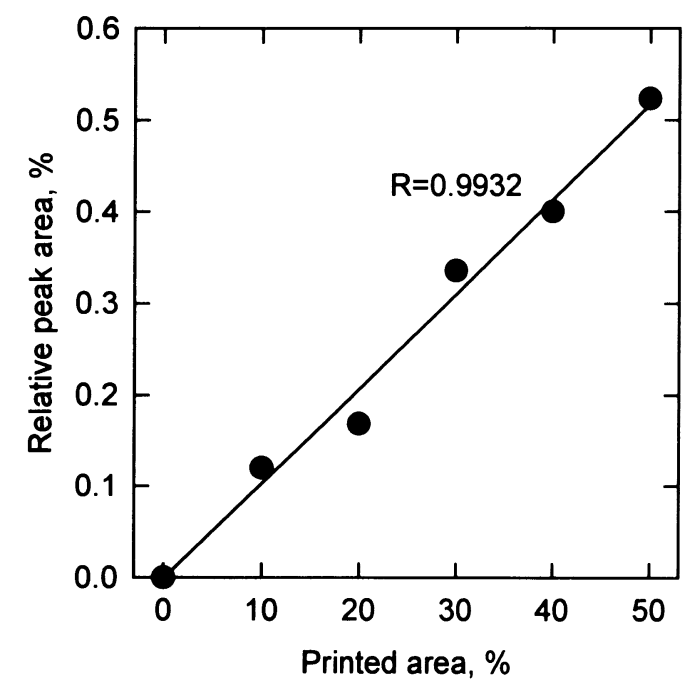

Fig.3 Relationship between printed area of wastepaper and relative peak area of toner obtained by pyrolysis-gas chromatography. 
$\mathrm{R}=\mathrm{P} \times 0.06$

ここで, $\mathrm{R}$ は再生紙の $\mathrm{g}$ 当なりの残留トナーの重 量 $(\mathrm{g}), \mathrm{P}$ は熱分解 GC で測定したトナー成分のピー クの百積比（熱分解 GC 全体のピーク面積に対するト ナー成分のピーク洎積）である。なお，トナーバイン ダーの種類が複数混入した場合には, トナーの種類に よって冬ピークの最がやや異なるため, 定量性は若下 変動する可能性がある。

(2) $\mathrm{k} / \mathrm{s}$ 值と门色度による分析

更に, $\mathrm{k} / \mathrm{s}$ 傎及び色度による残留トナ一量の定量 可能性について検討した。複数の成分からなる紙の光 学特性を評体する際に用いられるKubelka-Munk 理 論から，ある紙の $\mathrm{R}_{\infty}$ は式(1)のように記述される ${ }^{16)}$

$$
\mathrm{R}_{\infty}=1+\mathrm{k} / \mathrm{s}-\left[(\mathrm{k} / \mathrm{s})^{2}+2(\mathrm{k} / \mathrm{s})\right]^{1 / 2}
$$

ここで, $\mathrm{k}$ と $\mathrm{s}$ はそれぞれ吸收係数と散乱係数であ り， $\mathrm{R}_{\infty}$ は紙の吠さが無限大の場合の反射率である。 トの式(1)を $\mathrm{k} / \mathrm{s}$ について書き替えると，式(2)となる。 $\mathrm{k} / \mathrm{s}=\left(1-\mathrm{R}_{\infty}\right)^{2} / 2 \mathrm{R}_{\infty}$

そこで，式(2)から博牛:紙の $\mathrm{R}_{\infty}$ を实測し，コピ一面 積と得られる $\mathrm{k} / \mathrm{s}$ の関係を路べた。Kubelka-Munk の式から，トナー成分が微粒子となって均一にシート 中に你在していると伙定できれば，コピー面積と $\mathrm{k} / \mathrm{s}$ との間には直線関係が得られるはずである。図 4 に示 すように, コピー洎積の堌加, すなわち再生紙中の卜 ナ一の量が多くなればなるほど， $\mathrm{k} / \mathrm{s}$ 值も増加し，よ い垍線関係が得られた。この場合の相関係数は 0.9923 であり, $\mathrm{k} / \mathrm{s}$ 佔によっても残留トナ一量が定 量できることが六された。しかし，トナー自身の $\mathrm{k}$ 值， $\mathrm{s}$ 值については種類によらず一定と見て差し支えない

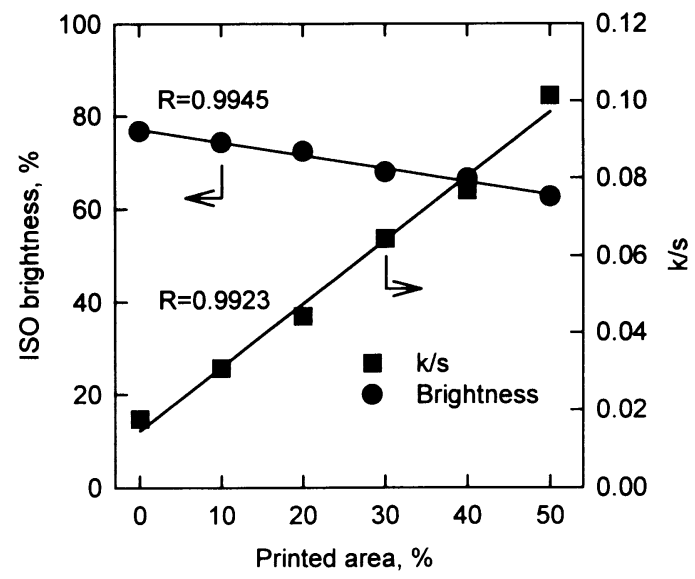

Fig.4 Relationship between printed area of wastepaper and either ISO brightness or $\mathrm{k} / \mathrm{s}$ value of recycled handsheets.
が, コピー用紙側の $\mathrm{k}$ 值, $\mathrm{s}$ 值が染料等の色材の混入 により変化した場合には誤差が生じるくるであろう。 コピー面積の増加による再生紙の白色度の変化は, 図 4 に示すようにコピー面積の増加, すなわち, 残留 トナ一量が増加するに従い直線的に低下した。白色度 は異なった光学特性を有する複数の紙の構成成分に対 して定量性が成り立つ根拠はない。しかし, 検量線が あればある程度残留トナー量を把握することができる ことを示唆している。

(3) 画像解析による分析

これまで, 再生紙の残留インキ量やトナ一量を把握 するために, 再生紙表面に占めるインキやトナ一面積 を画像解析によって求める方法が用いられてきた。そ こで，この方法について検討してみた。図 5 に示すよ うに, スキャナーで取り込んだ画像に対して，2つの しきい值で検討してみたが，いずれのしきい值を用い た場合でも，コピーの面積率がにがるに従つて直線か ら外れるようになり, 本実験で用いた方法では, 残留 トナ一量の定量法としては常に適用可能ではない。以 上の結果から, 原紙の光学特性によらずに残留卜ナ一 の絶対量を求める場合には, 熱分解 $\mathrm{GC}$ 及び $\mathrm{k} / \mathrm{s}$ 值 が適していることが示された。また，本実験の条件で は自度によっても残留トナ一量の変化を把握できる ことが分かった。

\section{2 脱墨処理温度が残留トナー量に与える影響}

図 6 には，離解処理の温度を 3 段階に変化させ，フ

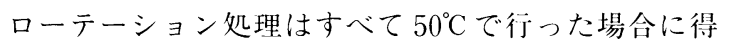

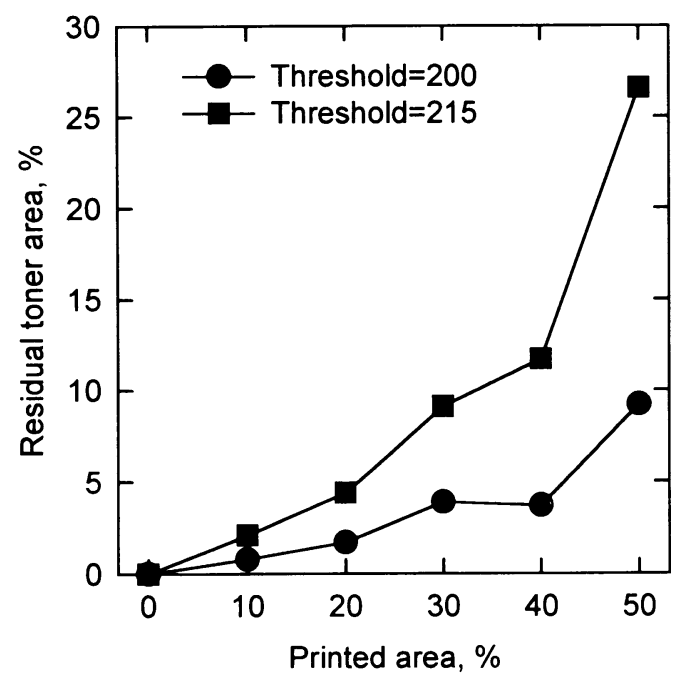

Fig.5 Relationship between printed area of wastepaper and residual toner area obtained by image analysis. 


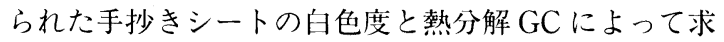
めた手抄きシート中の残留トナ一量の関係を示す。 $50 \%$ のピー面積の複写用紙を用い, 全体の処理とし ては表 1 の 5 の処理を行った。再生シートの収率 は約 $67 \%$ であり，この值は処理温度に関わらず一定

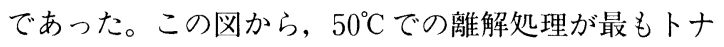
一成分の除去効率がよく, $70^{\circ} \mathrm{C}, 90^{\circ} \mathrm{C}$ と処理温度が高 くなるに連れて除去効率は低下し, 白色度も低下した。

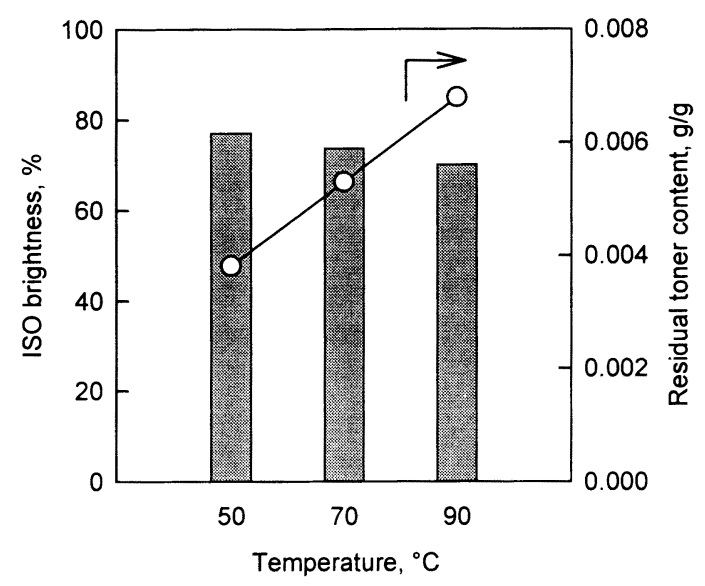

Fig.6 Effects of disintegration temperature on ISO brightness (bar graph) and residual toner content $(\bigcirc)$ of recycled handsheets.
図 7 には，本実験で用いたコピー用トナーの亦差走査 熱量 (DSC) 分析による変化のパターンを示す。卜 ナーバインダー由来と思われる $\mathrm{Tg}$ が $65^{\circ} \mathrm{C}$ に現れた。 従って，トナーバインダーの Tg 以.の温度でオフィ ス古紙の離解を行った場合, トナーバインダーが軟化 し, 粘着性が上がるためにパルプ纎維からの脱離性が 低下するものと考えられる。そこで本实験では，オフ イス古紙の離解一脱墨剂処理及びフローテーション処 理を $50^{\circ} \mathrm{C} て ゙$ 行った。

\section{3 脱墨処理過程におけるオフィス古紙の 構成成分の量的変化}

EDX 及び熱分解 GC の测定結果から, 本実験で用 いた複写用紙は填料として炭酸カルシウムを約 $5 \%$ 含 む中性紙で，サイズ剤としてはアルケニル無水コハク 酸（ASA）を用いていることが分かった。この複写 用紙に $50 \%$ の面積被覆率でコピーした試料を図 1 の 処理工程に従い脱星処理し, 表 $1 の \mathrm{~T} 1 \sim \mathrm{T} 5$ の処理 によって得られた再生手抄きシートについて構成成分 の量的変化を検討した。

（1）各処理における収率変化と繊維烓分布変化

T 1 T 5 の処理によって得られた手抄き再生シー トの収率を図 8 に示す。フローテーション処理を含ま ない, T 1, T 2, T 4 の処理では, 手抄き再生シート として得られた収率は 95\%程度であり, フローテー ション処理を含む T 3 では $74 \%$, フローテーション

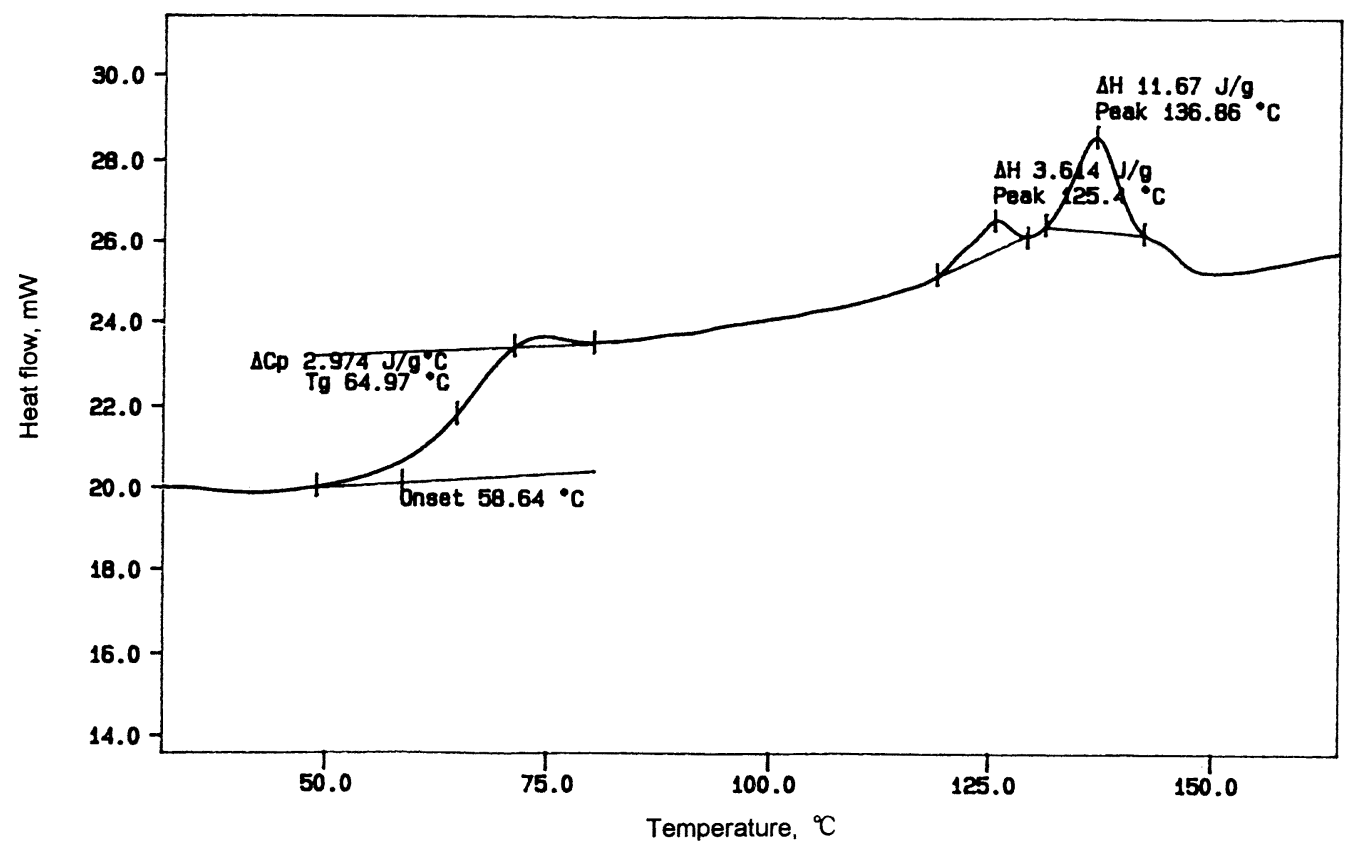

Fig.7 DSC curve of PPC toner. Measured at $5^{\circ} \mathrm{C} / \mathrm{min}$ in air atmosphere. 


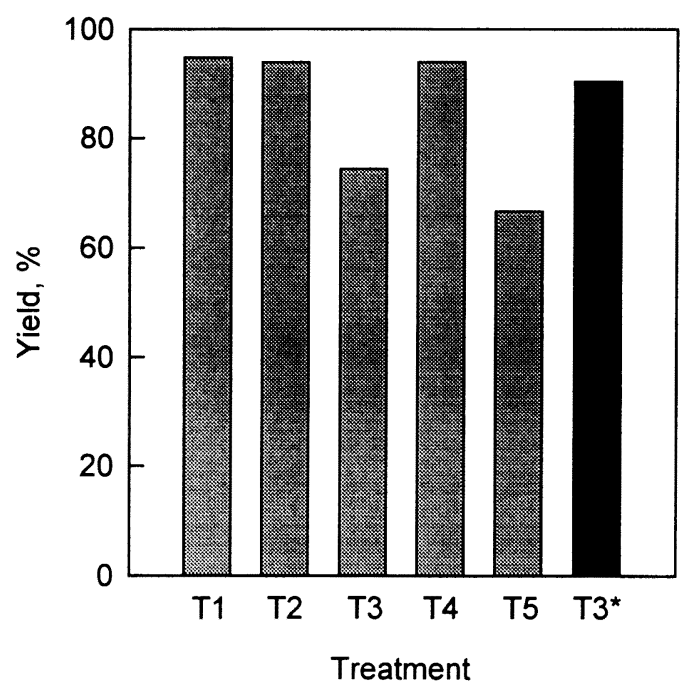

Fig. 8 Yields of pulps obtained by various deinking treatments of copied wastepaper. $\mathrm{T} 3^{*}$ represents disintegration of no -printed paper with $\mathrm{NaOH}$ and deinking agent followed by flotation treatment.

と漂白処理を含むＴ５では $67 \%$ となった。従って， フローテーション処理によって元の複写用紙の $25 \%$ 以上が失われたことが分かる。複写用紙そのものをコ ピーせずに離解一脱暏処理一フローテーション処理

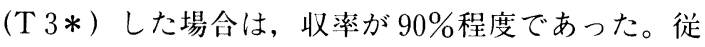
つて, T 3, T 5 の収率低下は, 脱墨処理の選択性の 低下によって, トナーが接着したままの状態でパルプ 瀻維ごとリジェクト部分に移行したことを示している。 これらの結果からも, 複写古紙の場合は, より脱墨選 択性の高い脱墨片及び脱墨処理が必要である。

図 9 には，複写用紙を解繊したパルプ及び，T 3 , $\mathrm{T} 5$ 処理でフローテーション操作後に得られた再生パ ルプの絨維长分们を示す。離解のみの場合と, フロー テーションを行った T 3 及び T 5 の場合とを比較し ても、中均䋐維埌及び纎維主分布はほとんど同じであ り, 特に微細繊維部分がフローテーション処理で除去 されることはない。従って，フローテーション処理後 の収率低下は, トナー成分のパルプ繊維からの脱離性 が低いことに由来する。

(2) 各処理における複写用紙中の構成成分の量的変 化

以下の構成成分の量的変化の検討は, 図 8 の収率で 得られた再生手抄きシートについて行った。

元の複写用紙に填料として約 $5 \%$ 含まれていた炭酸

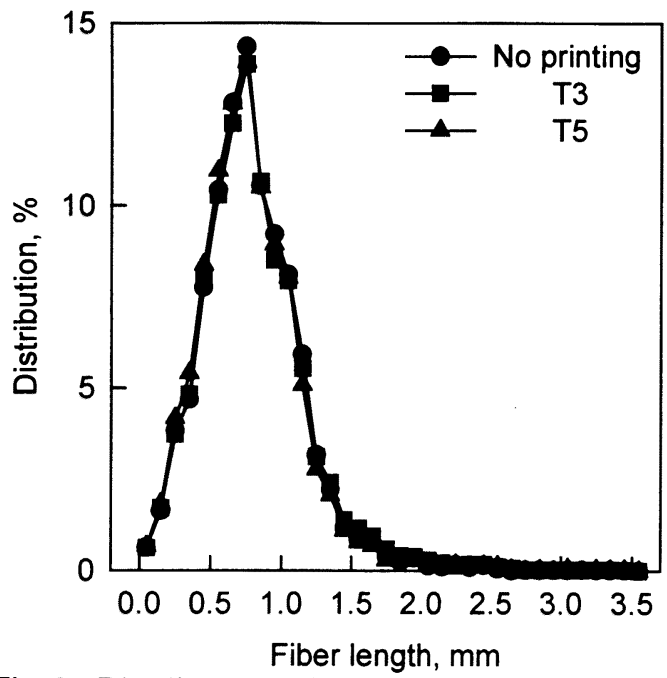

Fig.9 Distribution of fiber length of recycled pulps obtained by various deinking treatments of copied paper.

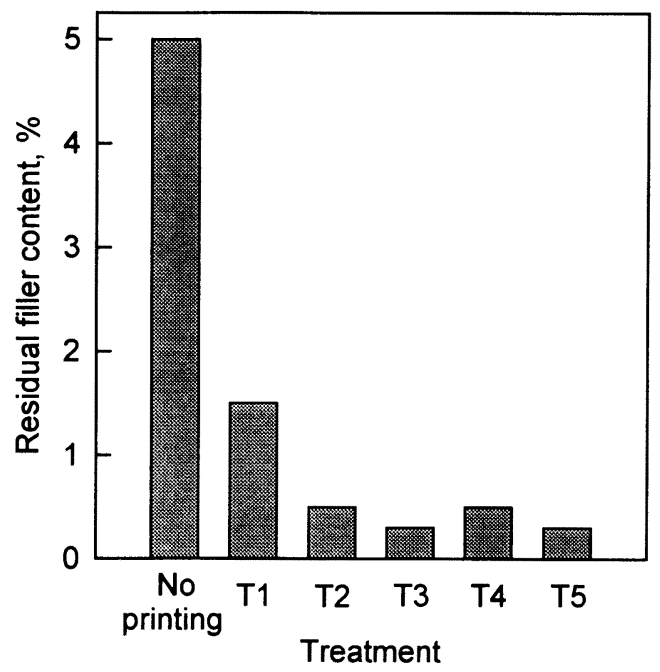

Fig.10 Changes in residual filler content of recycled handsheets by various deinking treatments of copied paper.

カルシウムの各処理段階における量的変化を図 10 に 示すが, 約 70\%の炭酸カルシウムが離解処理で除去 された。更に, 脱墨剤の添加やフローテーション処理 によっても除去され，全脱素処理工程後では $90 \%$ 以 上の炭酸カルシウムが除去されたことが分かる。この ような填料成分の除去は, 得られる再生紙の光学特性 にとってはマイナスの要因となる。すなわち, 脱墨処 理でも﨏料成分がある程度保持されれば，再生紙の白 
色度及び不透明度の維持に寄与するものと思われる ${ }^{17)} 。$ 一方, 電子顕微鏡観察による複写用紙中の啿料分布は ある程度凝集しており，このように一旦凝集した填料 成分を，再生紙中に保持させることは，均一なシート 構造形成にとってはかえってマイナスとなる可能性が ある。

内添サイズ剤である ASA 成分は，アルカリ性下の 離解処理のみで，そのほとんどすべてが除去された。 シート中の ASA 成分のほとんどは加水分解したアル ケニルコハク酸あるいはその塩としてシート中に存在 していることが報告されておりり帛，水酸化ナトリウム 存在下の離解処理中にナトリウム塩となって溶解除去 されたものと考えられる。

本実験で用いた複写用紙には約 $1.4 \%$ のデンプンが 含まれていた。このデンプン成分は, 歩留り剤あるい は乾燥紙力剤としてウェットエンドで添加されたもの と，表面サイズ剤として塗布されたものに由来すると 思われる。各脱墨処理過程でのデンプンの挙動を見る と，デンプン及び製紙用デンプン誘導体類は希アルカ リ水溶液に可溶であるため，そのほとんどがアルカリ 性下の離解処理で溶解除去されている(図 11)。従って, 紙中に含まれるデンプン量によっては離解処理排水に 負荷を与えることになる可能性がある。紙中デンプン 成分をアルカリ不溶化することができれば，フローテ ーション処理等で固形分として除去, あるいは再生パ ルプの一成分として再利用できる可能性がある。

$\mathrm{EDX}$ 分析で検出された複写用紙中のアルミニウム

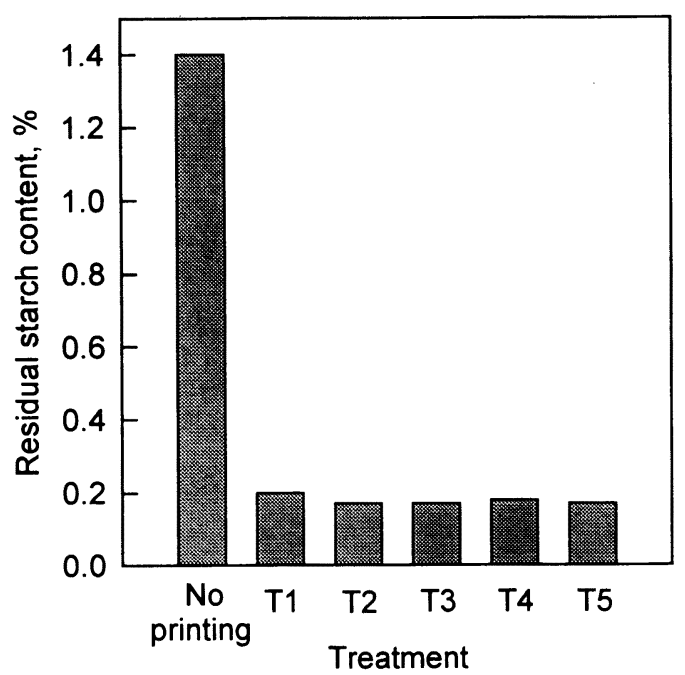

Fig.11 Changes in residual starch content of recycled handsheets by various deinking treatments of copied paper.

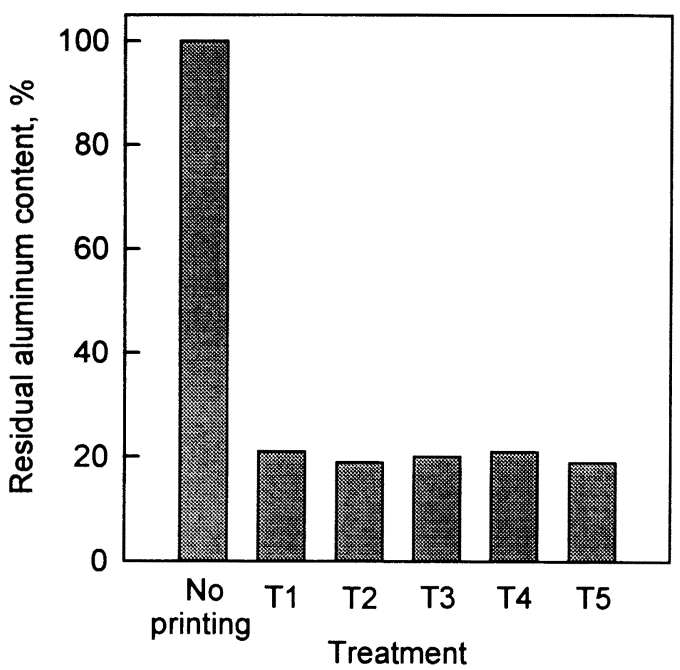

Fig.12 Changes in residual aluminum content of recycled handsheets by various deinking treatments of copied paper.

成分は，他の元素との関連から填料成分としてではな く，内添の硫酸アルミニウム由来と考えられる。この アルミニウム成分は，アルカリ性ドの離解処理でほぼ $80 \%$ が除去された（図 12）。

その後の脱墨処理やフローテーション処理, 漂白処 理後でも $20 \%$ 程度が再生シート中に残留しており， 複写用紙中のアルミニウム成分は, 希アルカリ性の離 解処理で容易に除去される部分と, 残留する部分に大 別された。このようなアルミニウム成分の挙動の差異 の原因については不明であるが，この複写用紙が中性 紙であることから，シート中のアルミニウム成分の構 造や分布の差を反映している可能性がある。

以上の結果から，元の複写用紙中に含まれていた填 料, サイズ剤成分, 步留り剤として用いられたアルミ ニウム成分, 更に内添及び表自サイズ処理で添加され たデンプン成分のほとんどは，アルカリ性下の離解処 理及びそのパルプによる手抄きシート調製の段階で除 去されることが示された。

(3) トナー成分の量的変化及び光学特性の変化 各脱墨処理での残留トナ一量の変化及び门色度, $\mathrm{k} / \mathrm{s}$ 值の変化をそれぞれ図 13, 図 14, 図 15 に示す。

熱分解 GC を用いた残留卜ナ一測定法を用いて脱墨 それぞれの段階においての残留トナーの量を測定した ところ，図 13 の T 1，T 2，T 4 に亦すように，離解 処理, 脱墨剂処理, 漂白処理の進行と共に残留トナ一 量が低下し，T 4 処理までで元の約 $17 \%$ のトナーが 除去された。しかし，依然として 83\%以ト:のトナー 


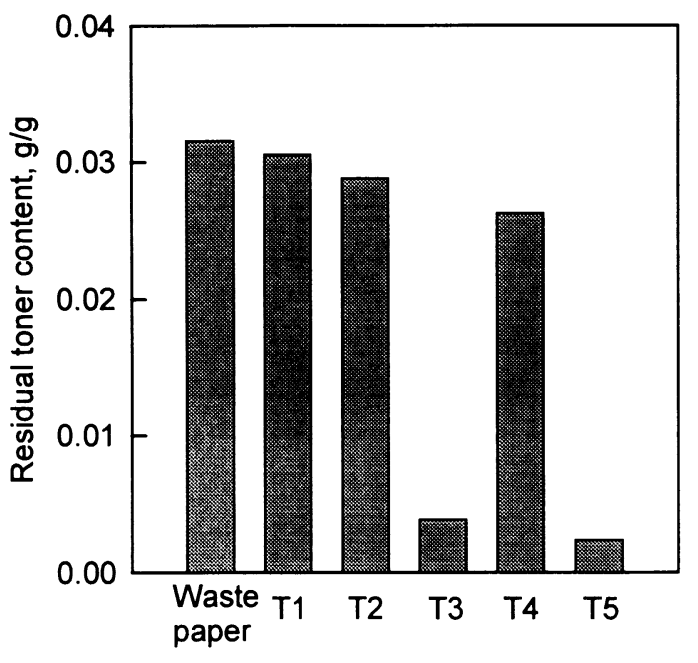

Treatment

Fig.13 Changes in residual toner content of recycled handsheets by various deinking treatments of copied paper. Printed area of the original copied paper was $50 \%$.

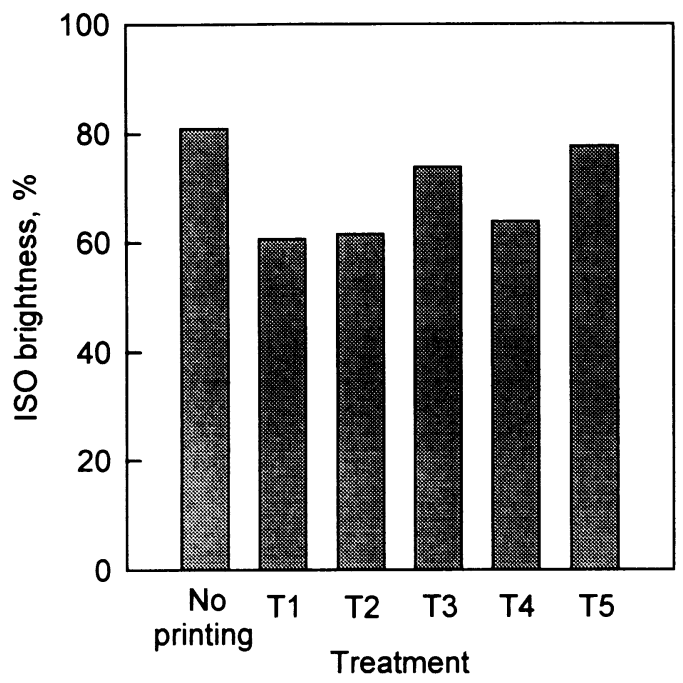

Fig.14 Changes in ISO brightness of recycled handsheets by various deinking treatments of copied paper. Printed area of the original copied paper was $50 \%$.

成分が残留しており，これらの処理のみによるトナ一 除去の効率は低い。一方, フローテーション処理を含 む T 3 及び T 5 の処理によって残留トナー成分は激 減し, T 3 で $83 \%$, T 5 で $92 \%$ のトナ一成分が除去

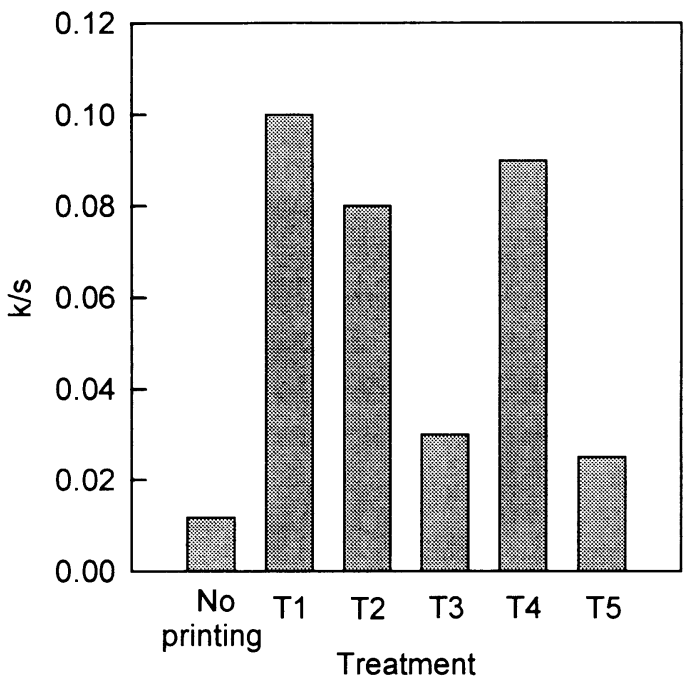

Fig. 15 Changes in $\mathrm{k} / \mathrm{s}$ value of recycled handsheets by various deinking treatments of copied paper. Printed area of the original copied paper was $50 \%$.

され，フローテーション処理がトナーの除去に必須で あることを示している。しかし，罒 8 に示すように， T 3 及び T 5 の収率はそれぞれ 74 及び $67 \%$ であり，

トナー成分の $80 \%$ 以上を除去するために，パルプの 収率低下を伴うことを示している。

図 14 には，T1～T 5 の处理における白色度の変化 を示す。T 1, T 2,T 4 処理による白色度の僅かな向上, T 3, T 5 処理による白色度の向上は, 図 13 の残留卜 ナー量の傾向とほぼ一致していた。図 15 には，k/s 值の変化を示した。 $\mathrm{T} 4$ 処理によって $\mathrm{k} / \mathrm{s}$ 值が増加し ているが, この理由は不明である。しかし, T 4 処理 の結果を除けば, 白色度の変化同様, $\mathrm{k} / \mathrm{s}$ 值も残留卜 ナー成分の量に対応している。

以上のように, 脱墨処理の各段階による残留トナー 成分量の変化は白色度, $\mathrm{k} / \mathrm{s}$ 值にほぼ対応しており, トナー成分は主としてフローテーション処理によって 一部分の纎維と共に除去された。従って，パルプ収率 をある程度維持しながら, 残留トナ一量を更に減少さ せるような処理が必要であることを示している。また， 今回の脱墨処理は，50\%の面積でべた塗り状態にコピ 一した試料を用いている。しかし，コピー面積の変化 やコピー状態の变化（細かい点によるコピー等）によ つて変化する可能性がある。実際，100\%べた塗状態 でコピーした試料を前述と同様, T 1 T 5 処理した ところ, 残留トナ一量の変化, 白色度の変化, $\mathrm{k} / \mathrm{s}$ 值 の変化は図 16, 図 17, 図 18 となり, 特にアルカリ性 


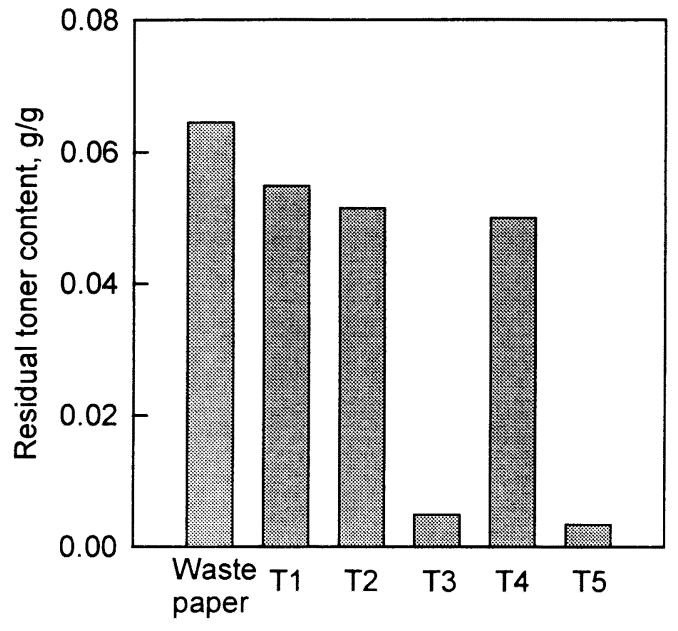

Treatment

Fig.16 Changes in residual toner content of recycled handsheets by various deinking treatments of copied paper. Printed area of the original copied paper was $100 \%$.

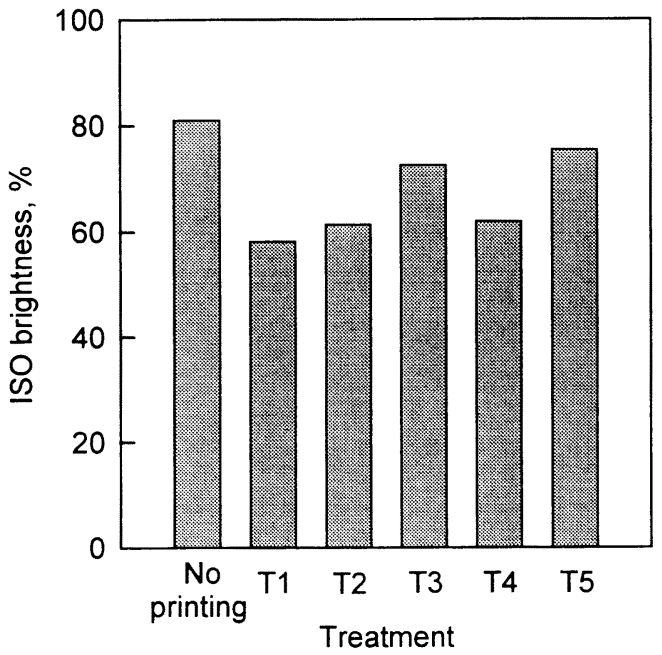

Fig. 17 Changes in ISO brightness of recycled handsheets by various deinking treatments of copied paper. Printed area of the original copied paper was $100 \%$.

下の離解処理で $40 \%$ 程度ものトナーが除去されてい る。なお，フローテーションによる除去の傾向は $50 \%$ のコピー面積の場合と同じであった。

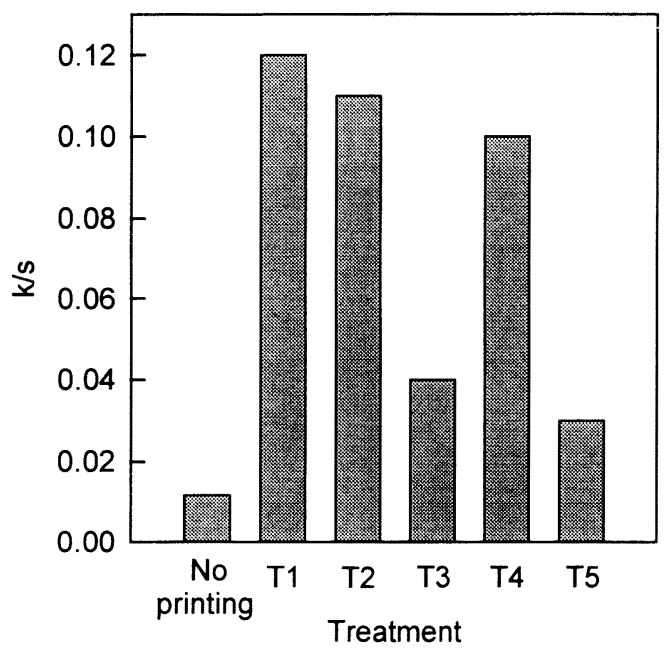

Fig.18 Changes in $\mathrm{k} / \mathrm{s}$ value of recycled handsheets by various deinking treatments of copied paper. Printed area of the original copied paper was $100 \%$.

4. 結論

（1）複写古紙の残留トナー量の評価方法として, 熱 分解 $\mathrm{GC}$ 法を検討し, 白色度, $\mathrm{k} / \mathrm{s}$ 值, 画像処理によ る結果と比較した。その結果, 熱分解 GC 法は残留卜 ナ一量の定量法として適していることが示され, 熱分 解 GCによるトナー成分のピーク面積比から残留トナ 一量を求関係式を導いた。

(2) 脱墨処理温度と残留トナ一量の関倸を検討した ところ, トナーのガラス転移点以下の温度で離解一脱 墨処理した再生紙中の残留トナ一の量が少なく，ガラ ス転移点以上ではトナーの除去効率が下がった。

(3) これらの知見を基にして, 複写古紙の各脱墨処 理過程での紙の構成成分およびトナーの量的変化を測 定した。その結果，元の複写用紙中に含まれていた填 料, サイズ剤成分, 歩留まり骺として用いられたアル ミニウム成分, 更に内添及び表面サイズ処理で添加さ れたデンプン成分のほとんどは，アルカリ性下の離解 処理及びそのパルプによる手抄きシート調製の段階で 除去された。

（4）脱墨処理の各段階による残留トナ一成分量の変 化は白色度， $\mathrm{k} / \mathrm{s}$ 值にほぼ对応していた。トナ一成分 は離解, 脱墨剤処理, 漂白では除去率が低く, 主とし てフローテーション処理によって微細纎維部分と共に, その $80 \%$ 以上が除去された。しかし，パルプ収率も 74〜66\%に低下した。これは，パルプ纎維が一部接着 
したままの状態のトナー成分がフローテーションリジ エクトとして除去されてしまうためである。従って, トナーとパルプ繊維の分離性を上げて, パルプ収率を ある程度維持しながら残留トナ一量を更に減少させる ような脱墨処理が必要である。

\section{謝 辞}

脱墨剂を提供いただいた花王株式会社及び, 纎維長 分布測定にご協力いただきました日本製紙株式会社中 央研究所の田部井宏一, 飯森武志の両氏に感謝いたし ます。

\section{引用文献}

1) PPI Annual Review, 37 (7), 19 (1995)

2) 本間彰：紙パルプ技術夕イムス，1994 年臨時増 刊号, p.97 (1994)

3) Matzke, W. : Sulzer Technical Review, 3, 11(1991)

4) Lumiainen, J. : Paper Tech., 35 (9), 41 (1994)

5) Jackson, L. S. ; Heitmann, J. A. ; Joyce, T. W. : Tappi J., 76 (3), 147 (1993)

6) Jeffries, T. W. ; Klungness, J. H. ; Sykes, M. S. ; Rutledge-Cropsey, K. R. : Tappi J., 77 (4), 173 (1994)

7) Anderson, J. : Sandoz Publication, p.176 (1995)
8) McCool, M. A. ; Taylor, C. J. : Tappi J., 66 (8), 69 (1983)

9) Gray, R. T. ; Simon, G. C. : Proc. Tappi Papermakers Conf., p.247 (1992)

10) Trepanier, R. J. : Pulp Paper Can., 95 (12), T 547 (1994)

11) Jordan, B. ; Nguyen, N. ; Trepanier, R. : Proc. Tappi Recycling Symp., p.377 (1993)

12) Borchardt, J.K. : Proc. Tappi Recycling Symp., p. 485 (1994)

13) Jordan, B. D. ; Popson, S. J. : J. Pulp Paper Sci., 20 (6), J 161 (1994)

14）林隆之, 津村直樹：紙パルプ技術タイムス, 9 月号, p.1 (1992)

15) Isogai, A. ; Nishiyama, M. ; Onabe, F. : Sen'i Gakkaishi, 52, 195 (1996)

16) Casey, J. P. : "Pulp and Paper-Chemistry and Chemical Technology", Vol. 3, p.1858 (1981) .

17) Borchardt, J. K. ; Rask, J. H. : Tappi J., 77 (9) , 161 (1994)

18) Nishiyama, M. ; Isogai, A. ; Onabe, F. : Sen'i Gakkaishi, 52, 180 (1996)

(受付 : '96.12.26) 